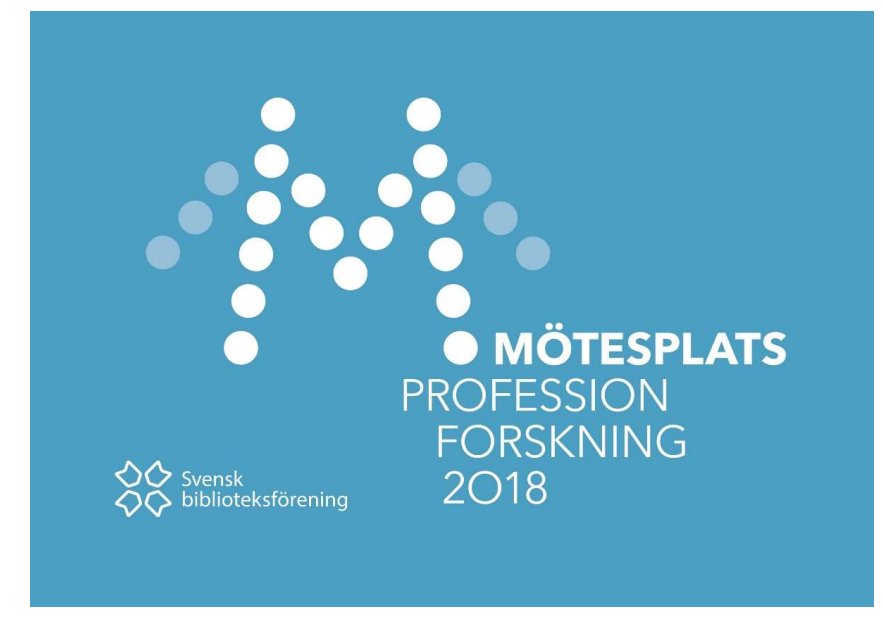

Jennie Aagesson, Cecilie Fonnesbech, Anna Hallberg, Ida Henriksson, Tove Lorentzon, Johanna Palm, Mattias Rieloff

Universitetsbiblioteket, Linnéuniversitetet

jennoie.aagesson@Inu.se cecilie.fonnesbech@Inu.se anna.hallberg@Inu.se

ida.henriksson@Inu.se tove.lorentzon@Inu.se johanna.palm@Inu.se mattias.rieloff@Inu.se

\title{
Sluta gissa! Strategier för att arbeta med UX i vardagen
}

\section{Problemformulering}

Varje dag besöker och använder studenter, forskare och allmänhet Linnéuniversitets bibliotek. Hur upplevs mötet med oss? Hur får vi reda på om utbudet av tjänster möter de behov som finns? Universitetsbibliotekets (UB:s) vision är att utgöra en kreativ kunskapsmiljö med innovativa och relevanta tjänster som stöd för att skapa, sprida och bevara kunskap (Linnéuniversitetets bibliotek 2015). För att kunna utveckla verksamheten $\mathrm{i}$ en riktning så att det motsvarar användarnas förväntningar har UB valt att på olika sätt arbeta med att öka medvetenheten om användarupplevelsens betydelse för utveckling av verksamheten. I verksamhetsplanen 2018-2020 uttrycks denna medvetenhet som ett tydligt mål: "[Att] skapa struktur och höja kompetensen för att UX (metoder för att undersöka användarupplevelsen) kontinuerligt ska användas i utvecklingen av verksamheten." (Linnéuniversitets bibliotek 2017).

Med utgångspunkt i ovanstående resonemang tillsattes vid årsskiftet 2017/2018 en fast arbetsgrupp på UB (UX-gruppen) som fick i uppdrag att:

- Skapa struktur och höja kompetensen för att UX kontinuerligt ska användas i utvecklingen av verksamheten.

- Skapa bra underlag för utveckling av UB:s tjänster genom att kontinuerligt undersöka användarupplevelsen.

- Höja kompetensen i UX-metodik och "UX-tänk" på UB. 


\section{Genomförande}

Ett mångsidigt tillvägagångssätt inledde arbetet med att etablera UX på UB. Arbetet har bestått av:

- att ta del av forsknings-, erfarenhets- och metodlitteratur inom området

- att praktiskt arbeta med UX för att utveckla bibliotekets discoverysystem (Ett discoverysystem är en samsökningstjänst som möjliggör sökning i bibliotekets samlade resurser - både fysiska och elektroniska.)

- erfarenhetsutbyte inom arbetsgruppen

- internkommunikation om UX inom UB för att öka kompetensen

- deltagande i konferenser inom ämnet

Bidraget till Mötesplats-Profession 2018 blir att utifrån arbetsgruppens uppdrag beskriva det arbete som hittills gjorts för att successivt införa UX på UB. Detta paper kommer att ge en bild av hur ett UX-arbete kan påbörjas i en biblioteksorganisation samt redogöra för de erfarenheter som gjorts så här långt.

\section{Bakgrund/litteraturgenomgång}

Vad innebär UX?

User Experience (UX) handlar om att utgå från användarens perspektiv i syfte att kunna förbättra och utveckla verksamhet. Både Anneli Friberg (2018), UX-bibliotekarie och Per Axbom (2017), UX-konsult beskriver UX som avsikten att förstå människors känslor, behov och beteenden i syfte att skapa bättre produkter och tjänster.

Enligt Andy Priestner (2017), UX-konsult, innehåller UX på bibliotek både inslag av etnografi och servicedesign. Priestner beskriver förhållandet utifrån en skala med etnografi i den ena änden och servicedesign i den andra. Det intervall/spektra som skapas mellan de både polerna ger i sin tur upphov till olika typer av user experience. Detta innebär i praktiken en balansgång mellan att använda sig av och skaffa sig kunskap om olika metoder för att på djupet kunna undersöka beteenden och attityder (etnografi), och att kunna utveckla relevanta tjänster för att effektivisera användningen (servicedesign). Priestners resonemang ger därmed en ökad insikt i att UX på bibliotek innebär en rörlighet på skalan och därmed en möjlighet att forma UX-arbetet utifrån de behov och förutsättningar som finns i organisationen.

Att implementera UX på bibliotek

Ett tema i litteraturen handlar om strategier och goda exempel på hur UX kan implementeras i en biblioteksorganisation. Sammantaget växer ett antal faktorer fram som kan ses som betydande för att kunna etablera ett gemensamt förhållningssätt till UX. Följande faktorer ser vi som en förutsättning för ett lyckat UX-arbete: systematiskt arbete, metodkunskap, ett organisatoriskt förhållningssätt och synliggörande av UX i visions- och andra strategidokument. 
Systematiskt arbete

Det finns ett antal modeller och praktiska exempel på hur ett UX-arbete kan systematiseras. Gemensamt för dessa arbetsmodeller är att de stegvis beskriver olika faser och vad som kännetecknar arbetet i respektive del.

I Andy Priestners (2018a) linjära modell "The UX Research \& Design Process" beskrivs följande faser där pilar illustrerar en möjlig rörelse mellan faserna:

Discover - att undersöka beteenden och attityder för att upptäcka problem och möjligheter, Define - att analysera resultaten och påbörja idégenerering,

Develop - att skapa en prototyp, inhämta feedback och göra nya förändringar,

Deliver - att lansera en produkt/service, utvärdera på nytt och eventuellt förändra.

Andra exempel på arbetsmodeller för att strukturera UX-arbetet finns på Linköpings UB och på Karolinska institutets bibliotek (KIB). På Linköpings UB utgår arbetet från en terminsvis grovplanering med inbokade tester som utförs månadsvis med hjälp av ett UX-team. Arbetet följer en modell, User-involvement/workflow for usability testing, som utgår från faserna: Planera, Testa och Förbättra och som upprepas i ett cirkulärt flöde (Friberg 2017). Ett kontinuerligt och småskaligt förbättringsarbete framhävs framför ett mer omfattande UXprojekt som kan vara resurskrävande (Friberg 2018). Denna ståndpunkt delas också av Steve Krug (2010) som betonar det informella "do-it-yourself testing" framför de större projekten i fråga om usability testing. Ett annat exempel på en arbetsmodell beskrivs av KIB i en poster som presenterades på Biblioteksdagarna år 2018. Modellen är även den cirkulär, upprepande och innehåller faserna: Bygga, Mäta och Lära (Säll et al. 2018). Sammantaget synliggör modellerna UX-arbetets huvudsakliga beståndsdelar, det vill säga både den undersökande delen (etnografi) och den utvecklande/skapande delen (servicedesign).

Metodkunskap

Samtliga modeller beskriver en undersökande fas där användarens behov, attityder och beteenden undersöks och där det finns en mängd olika metoder att tillgå beroende på studiens syfte. För att åskådliggöra valet av metod i relation till syftet med undersökningen har Christian Rohrer (2014) illustrerat ett metodlandskap som kategoriserar 20 olika metoder utifrån följande tre dimensioner:

- Undersöka attityder eller beteenden?

- Undersöka fenomenet kvalitativt eller kvantitativt?

- I vilket sammanhang ska fenomenet undersökas? (iscensatt användning eller verklig användning)

I Rohrers (2014) metodlandskap synliggörs variationen av olika sätt att undersöka ett fenomen vilket därmed underlättar valet av metod(er). En undersökning främjas av att flera metoder används för att kunna fånga in olika aspekter, vilket också påpekas av Friberg (2017). Krug (2010) lyfter även in möjligheten att anpassa omfattningen på användarundersökningarna efter de förutsättningar som finns i organisationen. Detta kan exempelvis innebära att rekrytering, antal deltagare, undersökning, analys och utveckling 
sker i en mindre skala men på en kontinuerlig basis. Hos Krug (2010) ligger fokus på att upptäcka de stora problemen och snabbt kunna åtgärda dem.

Organisatoriskt förhållningssätt

Det är viktigt att förhållningssättet till UX genomsyrar hela organisationen så att alla känner sig inkluderade och UX-tänket blir ett naturligt inslag i det vardagliga arbetet. Detta betonas och lyfts fram av flera olika författare som eftersträvansvärt för att skapa goda förutsättningar för ett strategiskt UX-arbete (Friberg 2018, McDonald 2017, Sheldon-Hess 2013, Säll et al. 2018, Priestner 2018b).

I Priestners (2018b) översikt Model of UX-learning and support beskrivs hur en verksamhet kan befinna och röra sig från ett initialt skede av UX-arbetet till att UX-perspektivet successivt blir mer inbäddad och integrerad i organisationens strategiska utvecklingsarbete. Sheldon-Hess (2013) beskriver en verksamhets UX-mognad i fem olika steg. Det första steget innebär att beslut fattas främst från medarbetarens olika föreställningar om ett fenomen medan det sista, femte steget, inkluderar UX som arbetssätt och underlag för all typ av beslutsfattning. På liknande sätt beskriver KIB en verksamhets olika mognadsnivåer i form av sex olika trappsteg, den så kallade UX-trappan. Det första trappsteget motsvarar ett icke erkännande av UX men efter varje trappsteg ökar acceptansen för och förhållningssättet till UX som beslutsunderlag inom organisationen. Syftet med att klättra uppåt i trappan och nå en högre mognad inom UX är att "skapa tjänster som ger värde både för användare och organisationen" (Säll et al. 2018). Inom samma tema, det vill säga att se UX som en gemensam organisatorisk uppgift, beskriver MacDonald (2017) betydelsen av att UX sprids i hela verksamheten för att säkerställa att fler blir involverade. Detta för att kunna genomföra användarstudier men också för att det användarstyrda perspektivet ska få genomslagskraft i organisationens strategiska arbete. En ytterligare effekt av ett sådant arbetssätt och inställning till UX är medarbetares möjlighet till kompetensutveckling och uppbyggnad av en gemensam kunskapsbas inom UX-området.

Synliggörande av UX i visions- och andra strategidokument Ytterligare en faktor som nämns av både MacDonald (2017) och i KIB:s poster (Säll et al. 2018) är vikten av att UX finns med som ett tydligt inslag i organisationens strategiska dokument. I KIB:s poster beskrivs ett antal mål som kopplar samman behovet av UX för utvecklingen av bibliotekets tjänster och service. MacDonald (2017) framhåller att för att säkerställa att införande av UX inte stannar vid ett nytt tankesätt eller omorganisation utan får en bestående förändring behövs strategier och riktlinjer för UX.

\section{Resultat}

I resultatdelen presenteras UX-gruppens erfarenheter så här långt och det ges exempel från den första omfattande UX-undersökningen på UB. Utöver litteraturläsning och strukturering av den inhämtade kunskapen, har den inledande tiden med UX-arbete ägnats åt att öka den interna medvetenheten om UX och möjligheterna att göra användarundersökningar, men också att genom praktiskt arbete lära oss mer om både metoder och analyser. Vi lär oss medan vi gör. 
Tre strategiområden

I arbetsgruppens uppdrag urskildes tre olika strategiska områden av relevans för det fortsatta arbetet: kompetens, tillgänglighet och utförande.

Kompetens

Ett av målen med UX-arbetet är att höja och utveckla kompetensen inte bara inom arbetsgruppen utan också inom hela UB och på så sätt öka organisationens UX-mognad. Inom arbetsgruppen arbetar vi mycket med kompetensdelning som skapar en gemensam förståelse för både metoder och teorier. Vid våra arbetsmöten lägger vi tid på att tillsammans läsa in oss, förklara för varandra men också att på olika sätt förmedla vidare till alla kollegor på UB. Ett sätt som vi arbetar på för att höja kompetensen internt på UB är att vi vid olika tillfällen har berättat om pågående UX-arbete, dels vid sektionsmöten men även vid "30 minuter om", ett internt föreläsningskoncept där kollegor bjuds in i syfte att kompetensutveckla.

Våren 2018 var UX-gruppen på ELUGSwes nätverksträff och presenterade vårt förhållningssätt angående att göra användarundersökningar på discoveryssystem. Målet för presentationen var att få till ett erfarenhetsbyte och att inspirera andra till att med enkla medel göra användarundersökningar. Budskapet är att en undersökning inte behöver vara komplicerad för att ändå ge intressant och användbar data. Delar av gruppen har också deltagit i UXlibs-konferens i Sheffield och fătt erfarenhetsutbyte, inspiration och erfarenhet av att testa metoder. Dessa erfarenheter har sedan delats i arbetsgruppen och i hela organisationen.

Ytterligare ett sätt att sprida kompetensen är genom de studenter på biblioteks- och informationsvetenskapsprogrammet som gör sin praktik, VFU (verksamhetsförlagd utbildning) hos oss och får prova att göra UX-undersökningar. För varje gång som arbetsgruppen introducerar UX-tänk och -metoder ökar vår egen medvetenhet. Det blir också ett tillfälle då vi genom VFU-studenterna lär oss mer om hur olika metoder fungerar. Studenterna går sedan tillbaka till utbildningen, förhoppningsvis med en ny insikt om att det kan vara enkelt och gå relativt fort att göra UX-undersökningar.

Tillgänglighet

Det andra strategiska området grundar sig i vår avsikt att arbeta både tillgängligt och utåtriktat. Vårt arbete ska vara tillgängligt på så sätt att vi har en transparens i alla delar, och utåtriktat genom att vi både vill dela med oss och bjuda in till nya arbetsformer och nätverk. Fokus är att skapa och samla men också att sprida och dela eftersom vi anser att nätverkande och delaktighet är grundläggande hörnstenar i UX-arbetet. I vårt arbete vill vi nå både externa och interna intressenter.

Inom den egna organisationen har tillvägagångssättet varit att löpande sammanfatta aktiviteter och resultat och genom ord och bild dela dessa med kollegorna inom UB. Vi prioriterar att dela information med våra kollegor oavsett om det framkommit förslag på 
förändringar eller om arbetet har givit resultat eller ej. En viktig aspekt av kommunikationen är att alla ska få insyn i arbetet och känna sig delaktiga.

Inom arbetsgruppen använder vi oss av webbverktyget Trello. Här samlar vi material för vår kompetensutveckling men även sådant som vi på olika sätt delar vidare med kollegor. I början kommunicerade vi internt på UB genom intranätet, Medarbetaren. Det finns dock begränsningar med intranätet som bristfällig sökmöjlighet som gjorde att våra inlägg försvann i mängden. Ett annat hinder var att intranätet förstås inte är öppet för externa UXintresserade som vill ta del av vårt material. I takt med den växande materialmängden ökade behovet av att ha en plattform att kommunicera genom. Valet av plattform föll på ett bloggverktyg, där vi framöver ska publicera inlägg och samla såväl reflektioner kring metoder som omvärldsspaningar.

UX blir allt vanligare inom bibliotekssektorn och vi vet att många runt om i Sverige gör och länge har gjort ett gediget arbete. Inspirerade av dessa vill vi vidareutveckla vårt UX-arbete $\mathrm{i}$ samarbete med kollegor från andra bibliotek. Därför har vi bjudit in tre andra bibliotek som arbetar med UX för att börja nätverka på ett informellt, praktiskt och prestigelöst sätt. Vår inställning till att arbeta med UX är inte att sprida ett perfekt resultat, utan att få möjlighet att bolla idéer och metoder under pågående undersökningar. Ett utåtriktat förhållningssätt där vi delar egna idéer och tar in andras tror vi resulterar i arbetssätt som blir mer användarvänliga i slutändan.

Utförande

Uppdragen och undersökningarna som UX-gruppen utför kan initieras av arbetsgruppen eller av kollegor från alla delar av biblioteksorganisationen. Här ger vi konkreta exempel från vårt praktiska UX-arbete från det första

uppdraget: användarundersökningar på universitetsbiblioteket discoverysystem, på UB kallat OneSearch. Anledningen till att detta var aktuellt att undersöka var att UB våren 2017 bytte system från EDS till Primo. Innan UX-arbetet påbörjades fanns en stor medvetenhet om vilka delar av OneSearch som upplevdes problematiska internt av kollegor, men hur användarna upplevde systemet kunde mest exemplifieras av små anekdoter från arbetet i informationsdisken. Målsättningen med valet av metoder för användarundersökningarna var att uppnå en variation i metoderna för att få ett utvidgat resultat. Syftet var att både få veta vad användarna säger att de gör och vad de faktiskt gör. Valet av metoder skedde också löpande under arbetets gång.

Ingången i användarundersökningarna blev att ta del av data som redan fanns tillgängliga och fokus lades på arkivet med chattar från användarna som inkommit via OneSearch. Vi läste igenom ca 800 chattar och sorterade upp dem i olika teman: fulltext, fasetter, reservationer och beställningar samt mina lån. Förutom de fyra teman vi kunde utkristallisera fanns övergripande problem med systemets språk som framstod som oförståeligt samt otydlighet gällande inloggningar.

Då våra användare framför allt chattar med oss när de har problem upplevdes ett behov av att komplettera chattgenomläsningen med love- and breakup-letters för att få fram nyanserade upplevelser av systemet. Dels ville vi gärna testa metoden och dessutom sammanföll det i tid med alla hjärtans dag. Metoden möjliggör både kritik och beröm samt 
ger utrymme för förbättringsförslag. Vi upplevde att metoden var enkel. Många användare ville svara och var väldigt positiva i sina skriftliga kommentarer. Ett möjligt problem med den här metoden är just att den ofta ger övervägande positiva svar, eftersom det kan kännas lättare att ge positiv än negativ kritik. Det material som kom in via love- and breakup-letters bekräftade de teman som framkommit vid chattgenomläsningen. Samtidigt framträdde en klarare bild av användarnas åsikter och upplevelse av systemet och vi identifierade ett behov av att komplettera materialet med att ta reda på vad användarna faktiskt gör och hur de interagerar med systemet, snarare än vad de själva säger att de gör.

Nästa steg blev därför att utföra användartester få att få reda på vad som faktiskt händer i mötet med discoverysystemet och vad användarna gör. Vi gjorde användartester med ett antal studenter och spelade in, skärm och ljud, när de försökte hitta en vetenskaplig artikel inom sitt ämne och bad dem tänka högt. Uppgiften som studenterna fick var att hitta en peer review artikel i fulltext. Metoden åskådliggjorde på ett tydligt sätt att vårt söksystem inte är självinstruerande utan kan upplevas som komplicerat och svårt att förstå. De inspelade scenarierna analyserades i arbetsgruppen. Vi utgick från Krug (2010, s.94) och listade för varje inspelning de tre största problemen som användarna stötte på. Efter analysen valde vi ut de allvarligaste problemen och planerade för ytterligare undersökningar av dessa områden. De övergripande problemen som vi kunde se efter analysen av användarstudierna var en upplevd osäkerhet kring systemet som sådant: vad händer när en trycker på en viss länk? Händer det som en förväntar sig eller inte? Språkliga konstigheter och otydlig layout var två andra områden som framstod som besvärliga för användarna. De flesta användare tyckte att det var självklart att börja med att googla vilket fick oss att fundera på varför det upplevs så mycket enklare och mer användarvänligt. Vi insåg dessutom att studenterna inte använde fasetterna i någon större omfattning och att många hade problem med att förstå de olika fasetternas rubriker och vad som händer vid användning av en viss fasett. Sammantaget gav läsningen av utsagor från användare och scenarierna oss en djupare förståelse för de problem som fanns i vårt system.

Utifrån analysen och de problem vi hade sett att användarna hade, bestämde vi oss för att utforska fasetterna närmare. För att undersöka användningen och förståelsen av fasetterna valde vi att göra en card sorting av rubrikerna. Vi bad studenter att sortera korten med rubriker och tänka högt kring vilka de upplevde som mest användbara. Vi fotodokumenterade alla olika sorteringar och kunde utifrån det urskilja ett tydligt mönster. Det blev påtagligt vilka avgränsningsmöjligheter som var de mest efterfrågade och använda men också vilka som var obegripliga eller som till och med orsakade förvirring. Efter att vi lagt samman alla resultat arbetade UX-gruppen fram ett förslag till justeringar av fasetterna som finns i Bilaga 1. Förslaget lämnades vidare till våra systemutvecklande kollegor för att implementeras i systemet. Efter våra undersökningar har enklare justeringar gjorts direkt $\mathrm{i}$ systemet och annat samlats för att ta ett större helhetsgrepp på OneSearch inför terminsstarten höstterminen 2018. Förslag som är under implementering finns i Bilaga 2.

I samband med användarundersökningarna av discoverysystemet blev det viktigt för UXgruppen att ha ett nära samarbete med systembibliotekarierna. Syftet var att bromsa takten på den löpande systemutvecklingen och inte gissa eller anta vad som är problematiskt för våra användare, utan faktiskt vänta och lyssna in deras upplevelser av systemet. Detta 
resulterade i veckovisa avstämningar för att diskutera kommande arbete hos både UXgruppen och systembibliotekarierna. Mötena har bidragit till ett tempo och ett arbetssätt som leder till att utveckling och upplevelse får samspela på ett konstruktivt sätt. Här har också de två olika perspektiven fått mötas: användarperspektivet och det mer tekniskt inriktade perspektivet, som styrs av vad som är systemtekniskt möjligt.

Parallellt med våra undersökningar hade UB under vårterminen 2018 besök av en holländsk student i "Information and Media Studies", Lowie van Eck, som i samband med sitt examensarbete gjorde användarundersökningar på OneSearch. Hans undersökningar var mer kvalitativa och planerade i förväg. Han utförde observationer av studenter och forskare som gjorde sökningar i OneSearch och ljud och intervjuer där intervjupersonerna fick svara på frågor om sina sökvanor. I van Ecks material fanns det stöd för att arbeta vidare med fasetterna. Hans studier resulterade dessutom i ett omfattande material som UX-gruppen kommer att analysera och arbeta vidare med.

Två UX-modeller

När vi läst in oss och tagit del av flertalet UX-modeller fanns ett behov av att bearbeta denna kunskap inom gruppen både för att applicera på vårt arbete i syfte att tydliggöra våra processer, men även som ett sätt att sprida UX-tänk och höja kompetensen internt. Modelltänket har vuxit fram under arbetets gång och fungerar som stöd där vi befinner oss just nu. Genom detta ser vi också vår egen resa och hur vår kompetens är en helt annan nu än när gruppen startade. Vi växer samtidigt som organisationen medvetandegörs. Med bakgrund i UX-litteraturen och från de erfarenheter vi fått genom det praktiska arbetet har vi utformat två modeller som vi använder i UX-arbetet. De två modellerna är i tur och ordning inspirerade av Priestner (2018a) och Rohrer (2014).

Fyrklövern

För att tydliggöra UX-arbetet både för oss själva i arbetsgruppen och inom vår organisation har vi skapat modellen "fyrklövern", en anpassning och översättning av Priestners (2018a) "The UX Research \& Design Process". Vi vill komma ifrån det linjära och poängtera relationen mellan processens fyra faser genom att sätta in dem i fyrklöverns blad. Bladen/ faserna överlappar varandra och mellan dem finns en öppenhet och en möjlighet att flytta sig mellan bladen/ faserna, inte nödvändigtvis till det som finns i steget innan eller efter. 


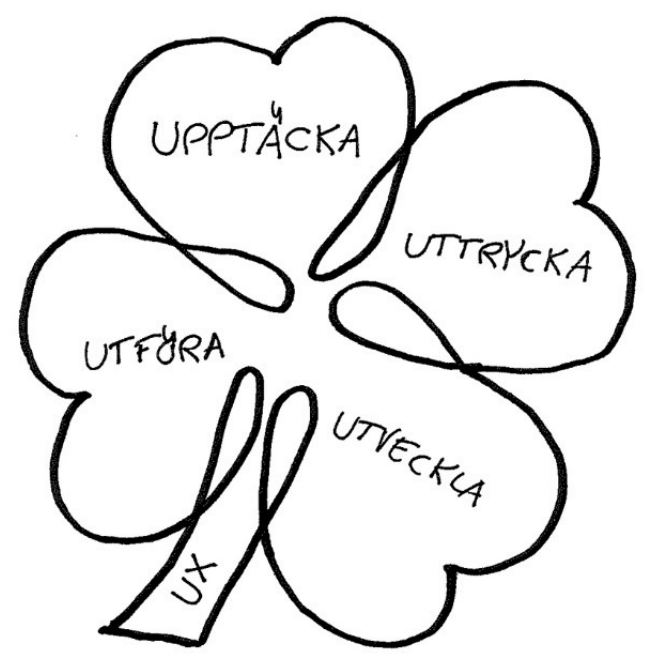

1. Upptäcka Ett problem identifieras, behovet av UX tydliggörs och undersökningarna genomförs. I detta blad kommer även vår andra modell in, fyrfältaren.

2. Uttrycka Detta blad inrymmer databearbetningen. Vi analyserar det insamlade materialet och definierar ett behov.

3. Utveckla I detta steg finns arbetet med att utifrån det uttryckta behovet utveckla och skapa ett förslag eller prototyp som tillgodoser det definierade behovet hos användaren.

4. Utföra Förslaget på förbättring implementeras. Sen återstår arbete med att följa upp och testa igen, vi återgår till de andra bladen som öppnar sig mot varandra.

Fyrfältaren

Rohrers (2014) modell tydliggör metodlandskapet inom UX och kan vara till stor nytta under Upptäcka-fasen. Vi har själva haft modellen som utgångspunkt vid val av undersökningsmetoder. För att förenkla vår interna kommunikation kring UX-metodologi men också ytterligare stärka vår lärandeprocess skapade vi en egen modell som illustrerar vårt UX-metodlandskap. Modellen kan användas som utgångspunkt i samtal med kollegor som har identifierat ett UX-problem för att underlätta vid val av vilken typ av undersökning som är önskvärd att genomföra. Fyrfältaren är dessutom en levande modell som utvecklas allt eftersom vi använder oss av och lär oss behärska fler och fler metoder. Att använda modellen är ett sätt för oss att arbeta systematiskt såväl som utforskande och lärandeorienterat. 


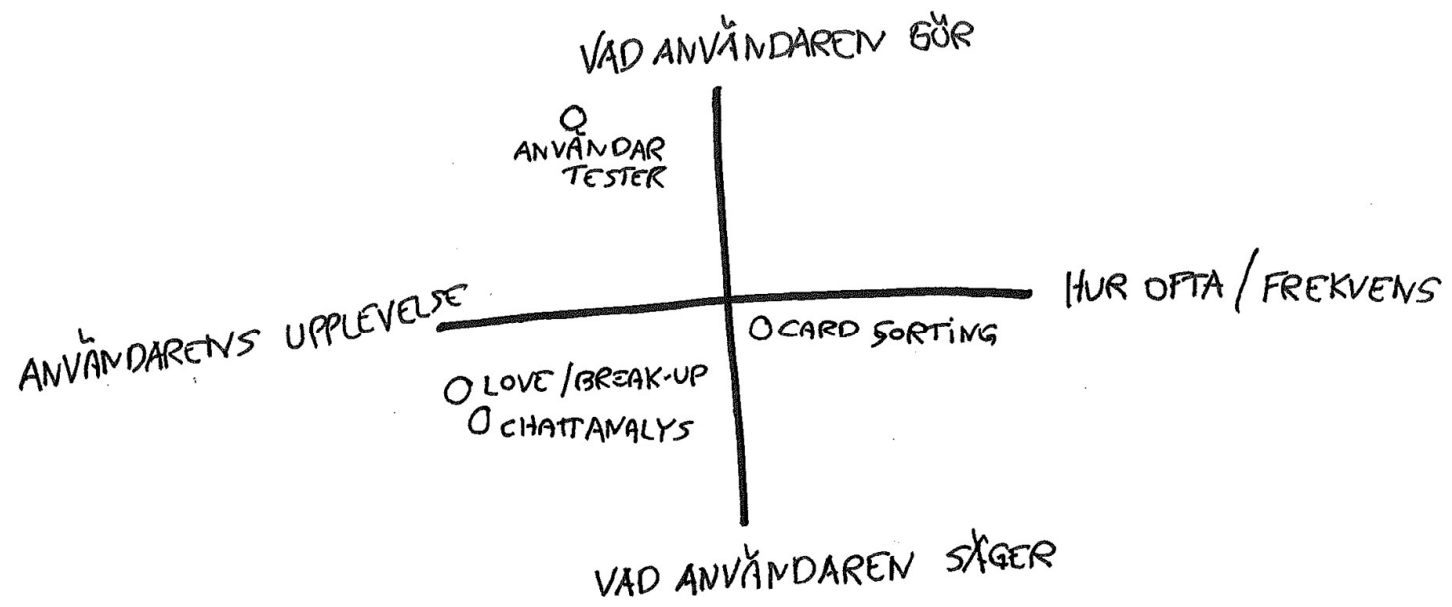

Modellens vågräta axel illustrerar huruvida behov finns att undersöka användarnas upplevelse eller företeelsens frekvens, alltså hur ofta något händer. Metoden som identifieras kan då vara av mer kvalitativ respektive kvantitativ natur. Den lodräta axeln illustrerar om vi är intresserade av vad användarna säger eller av vad de gör. Ytterligare en aspekt som vägs in, men som inte illustreras i fyrfältaren, är hur kontrollerad undersökningen ska vara. Där utgår vi från frågorna: "Vill du följa med oss?" som innebär att vi ger användaren instruktioner och därmed har kontroll över undersökningen, eller "Får vi följa med dig? vilken möjliggör ett mer förutsättningslöst förhållningssätt, där vi helt enkelt följer användaren efter deras premisser.

\section{Diskussion}

Efter ett knappt års aktivt UX-arbete kan vi konstatera att vi ser tecken på att UX börjar bli mer välkänt i organisationen. Vi är fortfarande i början av UX-implementeringen men kan redan se effekter av vårt arbetssätt. Genom att fortsätta arbeta på det sätt vi gjort under den första tiden ser vi hur organisationen kommer att mogna i sitt sätt att arbeta systematiskt med UX. Ambitionen är att smyga in UX-kompetensen i organisationen snarare än att frälsa vid ett tillfälle. Vi smyger upp för medvetenhetstrappan och organisationens UXmognad ökar gradvis enligt Sheldon-Hess (2013) modell. Vi lär genom att göra och genom att dela med oss av erfarenheter. UX-kompetensen vad gäller metoder och genomförande skaffar vi oss genom det kontinuerliga arbete som görs. Att medvetenheten om vikten av att ta med användarnas röster när vi utvecklar tjänster och innehåll börjar bli mer spridd $\mathrm{i}$ organisationen märks när det i olika sammanhang sägs: "Det här behöver vi UX:a!"

Målet är att det ska bli självklart att inta ett förhållningssätt där användarnas synpunkter har betydelse för verksamhetsutvecklingen. Förankringen av UX-arbetet i organisationen och formuleringar i verksamhetsplanen för perioden 2018-2020 säkerställer denna utveckling. Att UX finns med i de skrivna strategi- och visionsdokumenten är något som MacDonald (2017) lyfter fram som en avgörande faktor för att UX ska leda till en förändring i 
bibliotekets arbete. Vi ser också en utveckling där UX-arbetet på UB skulle kunna lyftas ytterligare med hjälp av systematisering i form av en mer långsiktig planering och årligen återkommande aktiviteter.

Att UX-frågan drivs av en fast arbetsgrupp som arbetar kontinuerligt säkerställer att användarperspektivet inte glöms bort. Arbetsgruppen ses för heldagsmöten då både planering av kommande undersökningar, analyser av insamlad data och idégenerering sker. Vid en del tillfällen har vi även använt våra arbetsmöten till att utföra undersökningar. Mellan arbetsmötena sker insamling av data men också förberedande analyser och i vissa fall inläsning av metodlitteratur. Då alla i UX-gruppen har olika roller och andra arbetsuppgifter i organisationen sprids kompetensen och medvetenheten dessutom i flera delar av organisationen samtidigt.

Utgångspunkten för UX-arbetet har varit att det ska vara enkelt och lätt att genomföra. Det måste inte heller vara helt "perfekt" genomförda undersökningar - alltid finns det något i det insamlade materialet som är användbart. Arbetet har balanserat mellan att följa metoder och ett mer fritt förhållningssätt, men målet har alltid varit detsamma: att på ett snabbt och enkelt sätt få in material, analysera och komma fram till ett resultat. Detta ligger i linje med Priestners (2017) resonemang: "The goal of user experience work, as I see it, is not purity of methods but a balancing of these methods with a practical effectiveness of outcomes." En ledande idé med UX-arbetet har varit att minimera mer tidskrävande arbete som det kan vara att exempelvis sätta samman fokusgrupper. Istället har arbetet skett med utgångspunkt i den aktuella situationen och vi kan utföra undersökningar och rekrytera respondenter när behovet uppstår. Vi har också låtit valet av metoder och tillvägagångssätt ske som en del av processen, här har vi haft nytta av vår modell "fyrfältaren" vid val av metoder. Genom att ställa oss själva frågan om vad vi är intresserade av att få reda på eller behöver komplettera vårt material med, har vi med denna modell valt typ av metod: Vill vi veta vad användarna tycker eller vill vi se vad de gör?

En lärdom från våra första undersökningar av discoverysystemet är vikten av att ha ett nära samarbete med kollegor även utanför UX-gruppen, i det här fallet systembibliotekarierna på UB. Det handlar både om att sprida UX-tänket men också att möjliggöra att resultaten från undersökningarna kan realiseras. Vid undersökningarna av discoverysystemet var det särskilt viktigt att UX-gruppen och utvecklare möttes för att få en gemensam förståelse för vad användarna upplever i mötet med systemet. Denna gemensamma förståelse ger förutsättningar för att utvecklingsarbetet går i en riktning som möter användarupplevelserna. Att användarperspektivet har fått en tydligare betydelse för utvecklingsarbetet på UB märks även genom att listan över önskade UX-undersökningar från olika delar av organisationen växer allt eftersom. Till exempel har arbetsgruppen fătt en förfrågan om att undersöka användarupplevelsen av UB:s ämnesguider.

En annan bidragande faktor till en lyckad implementering av UX är vårt valda arbetssätt: inför öppen ridå, vilket innebär att vi kontinuerligt bjuder in alla kollegor att följa vårt arbete via intranät och blogg. Det är ett arbetssätt som både bidrar till att skapa förståelse för metoderna, men som också gör att användarna får komma till tals genom resultaten. Här kan modellen "fyrklövern" användas för att på ett tydligt sätt åskådliggöra för kollegor hur UX-arbetets process ser ut. Arbetsgruppen ser värdet i att dela erfarenheter 
och resultat för att på så sätt lära och utvecklas och det nystartade nätverk för UX-frågor är ett av sätten detta kan ske på. Just vikten av att UX-bibliotekarier nätverkar med varandra är något som MacDonald (2017) framhåller som en av de viktigaste faktorerna när det gäller att lyckas med att bygga upp UX-kompetens på ett bibliotek.

Sammantaget karaktäriseras UX-arbetet på UB av ett förhållningssätt där undersökningar planeras löpande, täta avstämningar med kollegor med specialistkunskap (i våra undersökningar på discoverysystemet systembibliotekarier). Vidare är vårt UX-arbete öppet för vem som helst att följa och vi delar frikostigt med av oss av både våra processtankar, analyser och resultat. Genom små steg i vardagen skapas förutsättningar för ett mer långsiktigt arbete med målet att göra UX till en självklarhet i hela organisationen.

\section{Litteraturförteckning}

Axbom, Per (2017). Vad är UX - definitionen som gäckar oss [blogg], hämtad 13 juli 2018, från https://axbom.se/vad-ar-ux

Friberg, Anneli (2017). Why continuous usability testing can and should be part of regular library activity - from a UX librarian's point of view. Revy, 40(1), pp.9-11.

Friberg, Anneli (2018). Hon skuggar publiken. Biblioteksbladet, (3), s. 29-32.

Krug, Steve (2010). Rocket surgery made easy : the do-it-yourself guide to finding and fixing usability problems, Berkeley, Calif. : London: New Riders ; Pearson Education

Linnéuniversitetets bibliotek, (2015). Vision och strategi 2015-2020 - Universitetsbiblioteket. Linnéuniversitetets bibliotek, (2017). Verksamhetsplan, Universitetsbiblioteket för perioden 2018-2020.

MacDonald, Craig M. (2017). It takes village: on UX librarianship and buildning UX capacity in libraries. Journal of library administration, 57 (2), s. 194-214.

https://doi.org/10.1080/01930826.2016.1232942

Priestner, Andy (2017). What's in a name? Does it really matter whether we call it UX, ethnography, or service design? Weave: Journal of Library User Experience, 1(6). http://dx.doi.org/10.3998/weave.12535642.0001.603

Priestner, Andy (2018a). The UX Research \& Design Process [internet material]. Presentation vid UBLibIII, Sheffield.

Priestner, Andy (2018b). Model of UX learning and support [internt material]. Presentation vid UBLibIII, Sheffield. 
Rohrer, Christian (2014). When to Use Which User-Experience Research Methods. Nielsen Norman Group [blogg], hämtad 13 juli 2018, från https://www.nngroup.com/articles/whichux-research-methods/

Sheldon-Hess, Coral (2013). UX, consideration, and a CMMI-based model [blogg], hämtad 13 juli 2018, från http://www.sheldon-hess.org/coral/2013/07/ux-consideration-cmmi/

Säll, Johanna, Hägerbro, Karin, Samuelsson, Sofia, Albinsson, Sofie, Jenslin, Åsa (2018).

Användardriven utveckling på KIB. Om hur KIB arbetar aktivt och strukturerat med UX för att skapa tjänster som ger värde både för användarna och organisationen. Poster vid Biblioteksdagarna, Stockholm. 


\section{Bilaga 1}

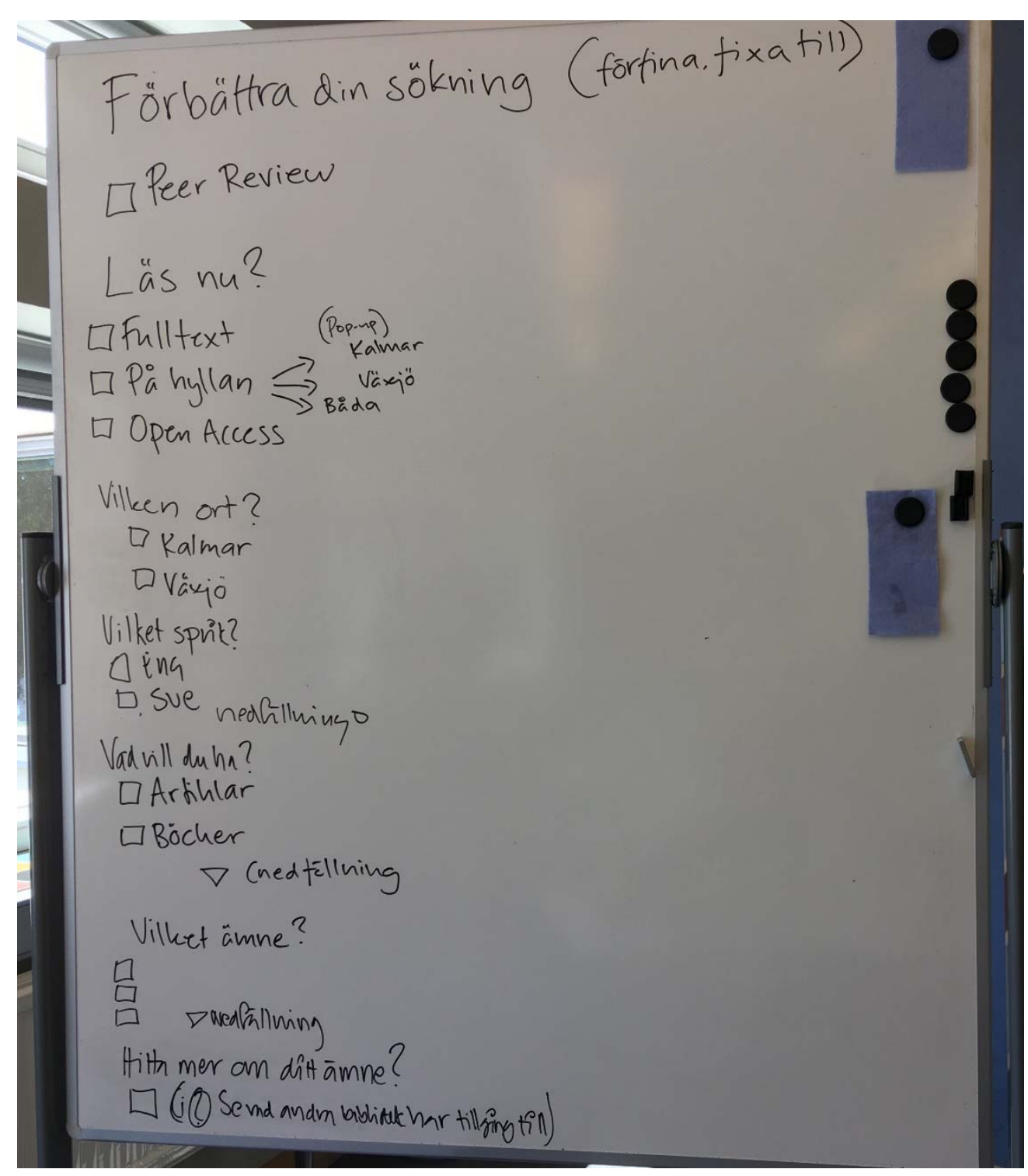

UX-gruppens förslag på utformning av fasetterna efter analys av card sortingen. 


\section{Bilaga 2}

\begin{tabular}{|c|c|c|c|c|c|c|c|c|c|c|}
\hline Linneiuniversitetet & taGGar & $\begin{array}{l}\text { NY SANDBoX. } \\
\text { SOKKNING }\end{array}$ & Journals & 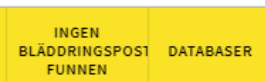 & $\begin{array}{l}\text { HÄॅTA } \\
\text { OBEKT }\end{array}$ & $\ldots$ & (3) & $\neq$ & SPRAKK & $\rightarrow$ LOGGAIN \\
\hline
\end{tabular}

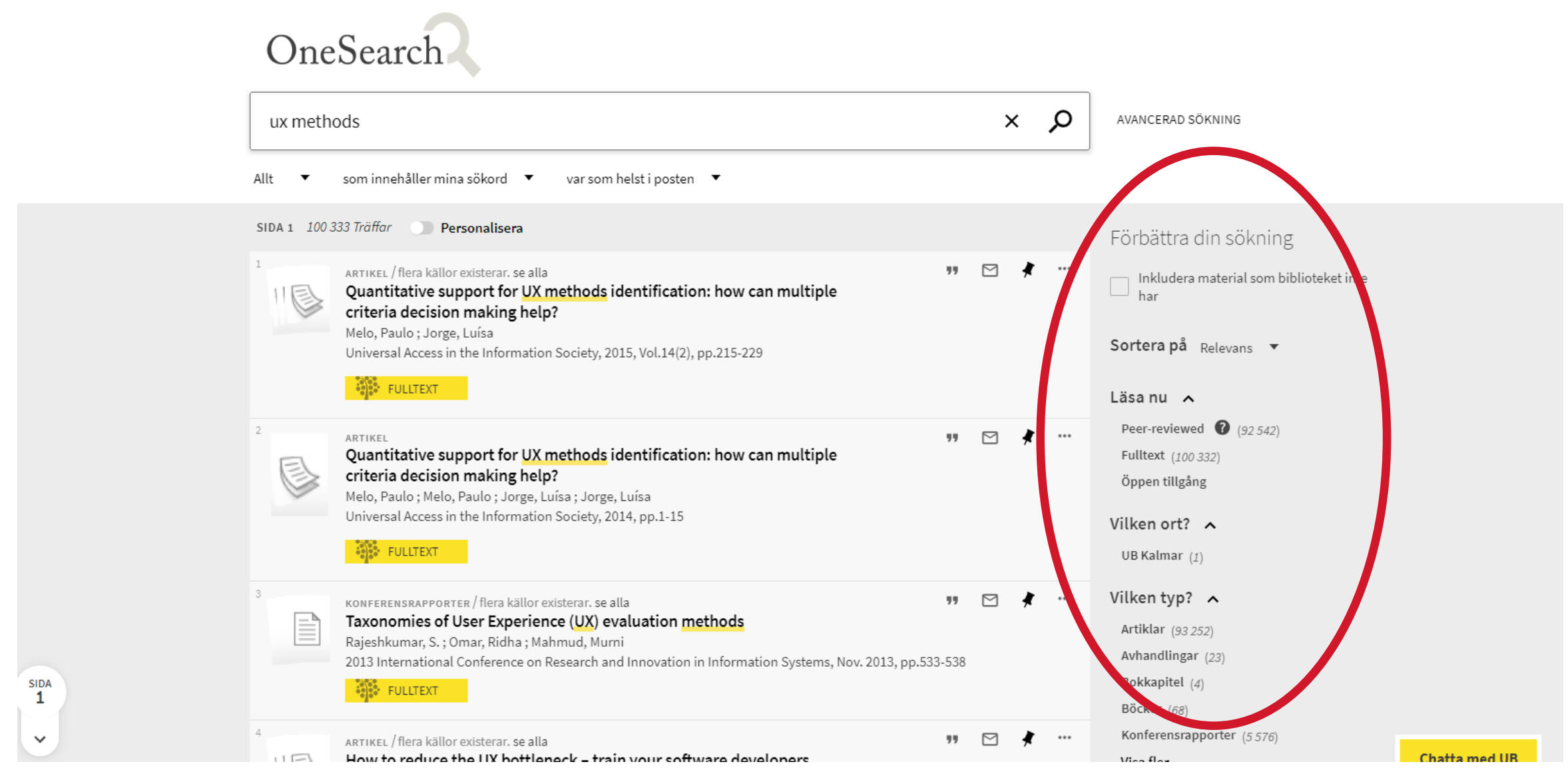

Fasetternas utformning efter systembibliotekariernas arbete. 